\title{
Arealogical and Ecotypological Compositions of the Flora of Plant Communities at Environment Contact Sites (Based on Some Pre-Baikal Sites)
}

\author{
Alexander Sizykh \\ Siberian Institute of Plant Physiology and Biochemistry SB RAS, Irkutsk, Russia \\ Email: alexander.sizykh@gmail.com
}

Received 15 June 2016; accepted 25 July 2016; published 28 July 2016

Copyright (C) 2016 by author and OALib.

This work is licensed under the Creative Commons Attribution International License (CC BY). http://creativecommons.org/licenses/by/4.0/

(c) () D Den Access

\begin{abstract}
The study of phytocenoses of transitional environmental conditions in the Pre-Baikal Region enabled to reveal modern tendencies of vegetation development in different Pre-Baikal sites. Such cenoses can serve as a regional model for indication of existing processes and of changes in vegetation structure which occurred under different environmental conditions. It is found out that ecotones and cenoses reflecting the paragenese in vegetation structure indicate structuraldynamic peculiarities of the organization of Pre-Baikalian vegetation cover as a whole. They are valid for classification and characterize intrazonal differences in vegetation structure at vaste territories. Ecotones and paragenese in the vegetation structure in the studied area reflect physical and geographical conditions of their formation for a definite time period.
\end{abstract}

\section{Keywords}

Areal, Ecotype, Flora, Plant Communities of Environment Contact Sites

Subject Areas: Biogeography

\section{Introduction}

The problem of assessment of ecosystems state and of the forecast of their changes in a whole and in the structure of vegetation covet in particular is a base of modern biogeographical, geobotanical, biogeocenotic and ecological studies. The main task is to study spatial-temporal self-organization of phytocenoses reflecting practically all changes in the environment during a concrete time period. To resolve it, a synthesis of different ways of their studies is necessary rather than a detailed analysis of separate components and elements of natural ecosystems. 
With such an approach, a phytocenosis is considered as a system, which forms and develops as a complex unit and forms mutually initiated links of matter and energy exchange with systems of other hierarchical level and ecotopes conditions both for separate species and for cenoses. The methods of determination of long-term trends of dynamics of vegetation cover structure are at different stages of development causing to researchers a series of problems-from choice of conceptual basis to notions and terms establishment for the revealed processes and states occurring in the vegetation cover and in whole ecosystems. The resolution of such tasks makes obviously necessary to correct the existing understanding of processes occurring in the vegetation cover and allows to find out a vector of their development within the system of natural factors at any territory. This results in appearing of basis to establish the age, the place and the role of current states of phytocenoses in successional systems. It is necessary for it to reveal the peculiarities of composition and assortment of phytocenoses resulting from natural environmental dynamics and from anthropogenic impact, especially for the vegetation from contrast environmental conditions.

At present, there is no unique approach to determine a sense of the notion "ecotone" while characterizing the structure of the vegetation cover under the condition of contrast (transitional) environmental conditions. This is partly due to the insufficiency of criteria determining the range of this notion. Due to this fact, this term is used for characterization of a transitional state both of vegetation in a whole environmental zone [1] and for forest adge [2] [3]. In some cases, "ecotone" is understood as well as a forest-steppe zone [4]. As a result, there is a term inversion, when different by their genesis and structure cenoses reflecting quite different physical geographical conditions of vegetation formation at a definite territory become subjects of the same range in the vegetation cover classification.

There is a greater misunderstanding for the term "paragenese" while characterizing spatial-temporal organization of vegetation. If in geography, geology, geomorphology and geochemistry it is rather established [5]-[9], in the field of vegetation the notion "paragenese" is up to present time as a subject of theoretical search with attempts to characterize a complex organization of cenoses of separate territories with this term [10] [11]. The listed above principal questions concerning classification of phytocenoses of environments contact (transitional environmental conditions) require a solution. The studies in this way are important both from scientific and from practical point of view as they allow to assess in more detail the changes in vegetation cover structure and to forecast its change.

The aim of this work is to find out the peculiarities of spatial-temporal organization of phytocenoses as ecotones between zonal forest-steppe and zonal steppe as well as one of phytocenoses reflecting the paragenes in the vegetation structure in the Baikal Region presenting concrete key sites. The following tasks were being resolved: to find out areological and ecotypological composition of the flora in the cenoses forming under the conditions of steppes extrazonality and at the boundary of forest-steppe and steppe environmental zones; to typify phytocenoses at environments contact sites (transitional natural conditions) between environmental zones, as well as phytocenoses of intrazonal environment differences; to determine vectors of formation of such phytocenoses under modern environmental conditions in the region.

\section{Studied Area, Methods and Materials}

The studied areas (key sites) are the following: middle part of the Selenga River basin (South-Western TransBaikal), middle part of the Barguzin Depression (North-Eastern coast of Lake Baikal). We have used in our work the method of field geobotanical survey. To reveal the links of phytocenoses with edaphic conditions in the habitats, we performed a combined soil-geobotanical profiling for the key sites at the studied territory. While classifying vegetation, we used a dominant approach with characterization of horizons species composition, which allows to reveal a spatial structure of phytocenoses from Arctic tundras to arid deserts under the conditions of zonality and height-belts. This approach is natural and fruitful in geobotanical mapping for revealing of the specifics of vegetation cover structure at different levels of its organization. The cenoses were united into associations by structure, dynamics and location similarity. The variable states of these associations were united in turn into epitaxa [12] as systems reflecting probable dynamical states of an association for definite locations during any time. The species composition of tracheophytes was determined according to "Flora of Central Siberia" [13], "Flora of Siberia" [14], compendium of Siberian flora [15], compendium of the flora of Asian Russia [16], and one of mosses - by the key "Frondiferous Mosses of Central Siberia" [17] and by "Outline of Siberian Brioflora” [18]. While performing geoelemental and ecotypological (ecotypes) analyses of the flora in the studied 
areas, we used stetements and recommendations of several researchers [19]-[30]. The work is based on the materials of perennial (1987-2015) studies of phytocenoses at key (model) sites of Baikal Region forming under the conditions of steppes extrazonality in the middle part of Barguzin basin and middle part of the Selenga River basin, of the territory of transition of zonal forest-steppe into zonal steppe. The ecotopes were classified on the base of the ecological morphology of plants [24] [25]. The geoelements were determined on the base of the peculiarities and genesis of Siberian flora [21].

\section{Results}

Natural and climatic conditions of the region are presented in numerous specialized maps, atlases and papers and reflect these or those characteristics of regional environments and structural peculiarities of the vegetation cover on the territory of the Baikal Region from first papers by M.F. Korotky [31]-[34] up to present-day researchers [35]-[38]. Because this kind of information will take much more places in the paper that way we mentioned only authors why made this research for long time investigation of the zonal forest of North Trans-Baikal and transition territory of zonal forest-steppe to dry zonal steppe of South-Western regions.

We believe that it is possible to present only several rather specific characteristics of the factors of phytocenoses formation in the description of environmental conditions directly for each key site which are representative for concrete areas of the whole Baikal region. In the system of geographical zonality by heat and humidity ratio, the latitudinal zonality is primary, and height belts are secondary. Due to changes in solar radiation at the boundary of transition of atmospheric moistening (from oceans deepward to the continent), the latitudinal zonality in mountain systems is substituted by height belts, which is in a definite belt of solar radiation. I.e., in the mountains, the height belts are determined by the intensity of solar radiation of a definite radiation belt on the general background of heat and humidity ratio in the aspect of latitudinal zonality [39].

\subsection{Key Site-Middle Part of the Selenga River Basin (South-Western Trans-Baikal)}

The basis vegetation of this key site consists of taiga (boreal) vegetation of Ural-Siberian fratria of formations of mountain taiga pine and larch pine grass-brush forests in combination with pine grass-brush stepped forests and small-bunchgrass steppes of South Siberia formations of forb-cereal and cereal steppes [40]. According to the zones map and belts types of vegetation of Russia and adjacent countries [41], the phytocenoses on the territory of the key site are included in boreal (taiga) West Pre-Baikalian forest-steppe and steppe (Kyakhta) vegetation belt. Here, in the Selenga forest steppe, there are rather widely extended steppe cenoses consisting of Elytrigia repens (L.) Nevski, Iris biglumis Vahl.. There are synusial cenoses with dominating Caragana spinosa (L.) DC., as well as galophyte cenoses with Kalidium foliatum (Pallas) Moq. and Nitraria sibirica Pallas. There are as well cenoses with dominating Stipa pennata L. usial for Khakasya-Minusinsk steppes and for the Pre-Angara Region. Zonal forest-steppes are presented by cenoses formed at a limited territory along the slopes of different expositions; they reflect the features of light coniferous forb forests and of steppe cenoses of a zonal steppe. The common table represents main composition of vegetation species for the studied area. The specifics of edaphic (transition of forest-steppe zone into steppe one in presence of soils characteristic for forest-steppes) conditions, one of climate fluctuation in the region during last decades including our studied area resulted here in formation of a rather great diversity of ecotopes characterizing spatial and vertical heterogeneity of phytocenoses structure and dynamics. Under the conditions of forest-steppe and steppe contact, as a result of environmental conditions specifics, the cenoses based on plants species with definite ecological features form here.

We performed an arealogical analysis (see Table 1) of flora in the cenoses forming under the conditions of zonal forest-steppe with transition into a steppe environmental zone of Central Asia. The revealed types of a geoelement (areals types) and ecotypological (ecotypes) of plants species composition are based on principles presented in the papers listed in the Introduction. Among main phytocenoses species composition on the key site, the fraction of mesophytes themselves (eumesophytes) and xeromesophytes represent major quantitative ratio of plants of total florictic composition of the cenoses, a smaller fraction consists of plants of xerophytic ecology (mesoxerophytes and euxerophytes). As it results from statements for determination of chorologic (areals) and belt-zonal groups [21], the floristic composition of key sites cenoses is characterized by forest-steppe and light coniferous-forest belt-zonal groups with predominance of plants with Eurasian and North-Asian types of geoelement (see Table 1). There are significantly presented species of South-Siberian, Mongolian and CentralAsian with presence of circumpolar (holarctic boreal) geoelements. This reflects the specifics of environmental 
Table 1. Common table of plants species characteristic for the key site (the Selenga R. basin).

\begin{tabular}{|c|c|c|c|c|c|}
\hline \multicolumn{6}{|c|}{ Geoelemental and ecotypological composition of the basic plant species of the key area } \\
\hline Plant species & Geoelement & Ecotype & Plant species & Geoelement & Ecotype \\
\hline Pinus sylvestris & EA & $\mathrm{XM}$ & Dracocephalum ruyschiana & EA & $\mathrm{XM}$ \\
\hline Larix sibirica & ES & MT & Equisetum sylvaticum & $\mathrm{CP}(\mathrm{HA})$ & MT \\
\hline Betula pendula & ES & MT & Sanguisorba officinalis & $\mathrm{CP}(\mathrm{HA})$ & MT \\
\hline Spiraea media & EA & MT & Poa botryoides & CA & MX \\
\hline Cotoneaster melanocarpus & NA & $\mathrm{XM}$ & Artemisia absinthum & EA & MX \\
\hline Rosa acicularis & CP (HA) & MT & Astragalus subfrutocosus & SC & MX \\
\hline Carex pediformis & EA & MX & Pedicularis venusta & SC & MT \\
\hline Carex macroura & NA & MT & Vicia baikalensis & E-A & MT \\
\hline Pulsatilla multifida & CP (HA) & MT & Carex duriuscula & AA & $\mathrm{XT}$ \\
\hline Bupleurum sibiricum & MD & XM & Trifolium pratense & ES & MT \\
\hline Scorzonera radiata & CA & $\mathrm{XM}$ & Myosotis arvensis & CP (HA) & $\mathrm{HM}$ \\
\hline Crepis sibirica & EA & MT & Papaver popovii & EN & $\mathrm{XM}$ \\
\hline Thalictrum foetidum & EA & $\mathrm{XM}$ & Taraxacum officinale & SC & MT \\
\hline Phlomis tuberosa & EA & XM & Allium tenuissimum & SC & $\mathrm{XM}$ \\
\hline Potentilla bifurca & $\mathrm{EC}$ & $\mathrm{XM}$ & Poa pratensis & EA & MT \\
\hline Myosotis imitata & CP (HA) & MT & Rumex acetosella & $\mathrm{CP}(\mathrm{HA})$ & MT \\
\hline Vicia cracca & C-A & MT & Festuca lenensis & NEA & CrX \\
\hline Polygala sibirica & EA & MT & Artemisia frigida & CP (HA) & CrX \\
\hline Draba nemorosa & CP (HA) & MT & Potentilla acaulis & CA & $\mathrm{XT}$ \\
\hline Galium verum & CP (HA) & MT & Orostachis spinosa & CA & CrX \\
\hline Astragalus austrosibiricus & NA & MX & Veronica incana & NA & MX \\
\hline Polygonatum odoratum & EA & MT & Aster alpinus & CA & CrX \\
\hline Ranunculus borealis & EA & MT & Clausia aprica & EA & $\mathrm{XT}$ \\
\hline Fragaria viridis & ES & MT & Potentilla tanacetifolia & SC & XM \\
\hline Alopecurus pratensis & ES & MT & Thymus serpyllum & SC & $\mathrm{XT}$ \\
\hline Trollius asiaticus & SC & MT & Goniolimon speciosum & EA & $\mathrm{XT}$ \\
\hline Filipendula ulmaria & EA & MT & Eremogone meyerii & SC & MX \\
\hline Urtica dioica & $\mathrm{OKh}$ & MT & Heteropappus altaicus & C-A & $\mathrm{XM}$ \\
\hline Maianthemum bifolium & EA & MT & Artemisia laciniata & NA & MX \\
\hline Plantago major & $\mathrm{CP}(\mathrm{HA})$ & MT & Iris humilis & EA & MX \\
\hline Stellaria cherleriae & SC & MT & Androsace lactiflora & NA & XM \\
\hline Thalictrum foetidum & EA & MT & Stipa sibirica & NA & XM \\
\hline Trifolium repens & EA & MT & Chamaerhodos erecta & NA & MX \\
\hline Pyrola rotundifolia & CP (HA) & MT & Trifolium lupinaster & EA & MT \\
\hline
\end{tabular}


Continued

\begin{tabular}{cccccc}
\hline $\begin{array}{c}\text { Koeleria cristata } \\
\text { Capsella bursa-pastoris }\end{array}$ & CP (HA) & XT & Alyssum obovatum & CA & CrX \\
Artemisia vulgaris & CP (HA) & MT & Erysimum flavum & NA & ГалXM \\
Agrostis gigantea & CP (HA) & MT & Taraxacum mongolicum & E-A & XT \\
Atriplex sibirica & C-A & MX & Carex korshinskyi & E-A & MX \\
Chelidonium majus & EA & MT & Androsace incana & SC & CrX \\
Euphorbia discolor & NA & XM & Schizonepeta multifida & NA & MX \\
Leymus chinense & C-A & MT & Astragalus adsurgens & E-A & XM \\
Calamagrostis epigeios & EA & XM & Serratula centauroides & SC & XM \\
Plantago media & EA & MT & Ptilotrichum tenuifolium & SC & XT \\
Stipa krylovii & C-A & MT & Agropyron cristatum & CA & MX \\
\hline
\end{tabular}

Table legend: EA—Eurasian geoelement; CA—common Asian one; AA—American-Asian one; EA-East-Asian one; NEA-North-East Asian one; ES - Eurosiberian one; SC-South-Siberian and Mongolian one; MD-Manchuria-Daurian one; OKh-Okhotsk one; NA-North-Asian geoelement; E-A_East-Asian one; C-A—Central-Asian and CP (HA)—circumpolar (boreal holarctic) one and EN-endemic geoelements, respectively; MXmesoxerophytes; XM-xeromesophytes; MT—mesophytes themselves; XT—xerophytes themselves; HalMX—halomesoxerophytes; HM-halomesophytes and $\mathbf{C r X}$ — cryoxerophytes, respectively.

conditions where one can observe processes of mutual invasion of plants from mountain forest-steppe zone into a steppe zone, and the key site (middle part of the Selenga River basin) is situated within the territory of the contact of Orkhon-Lower Selenga mountain-forest-steppe subprovince and mid-Khalkhass steppe subprovince of Central-Asian (Dauria-Mongolia) subregion of Eurasian steppe area [42]-[44]. This results in formation of transitional (interzonal) phytocenoses in the region. It is suggested as well by geoelemental and ecotypological composition and by ratio of belt-zonal groups of plants species in the structure of cenoses from the key site (Table 1).

In some locations of the cenoses (on the base of geobotanical descriptions) mosses of a wide ecological amplitude characteristic for polydominant light coniferous forests occur extremely rarely, synusially. These are such species as Abietinella abietina (Turn.) Fleisch., Polytrichum piliferum Hedw., Ceratodon purpureus (Hedw.) Brid., Funaria hygrometrica Hedw., Pylaisia polyantha (Hedw.) BSG., Orthotrichum rupestre Schleich. ex Schwaeger. Essentially, these cenoses form an interzonal ecotone. Consequently, they can be used for monitoring of spatial variability of vegetation cover in environmental zones of South-Western Trans-Baikal on the background of climate dynamics in the region during last decades.

The structure of forb stepped forests in the studied area reflects the tendences of increase of undergrowth amount since 1970ies. The dynamics of reconstitution processes in the forests under the conditions of zonal forest-steppe reflects differentiation of surface cover by horizons, abundant undergrowth with tendency to further forestation of open steppe sites both within the zone of mountain forest-steppes and at contact site with the steppe zone. The performed soil-geobotanical profiling allowed to reveal a rather tight correlation of vegetation structure with soils. Forests and steppe cenoses are rather closely linked with soils types characteristic for definite elements of the relief structure; this is appropriate to mountain forest-steppes where vertical belts are manifested (or height zonality, by: Reimers [45]) in the spatial structure of regional vegetation. "Grass cover in the forest-steppe is rather diverse by its species composition... at elevation of steppe sites upward the slope, increase of hydrophilous forbs and decrease of cereal components are observed, and while approaching taiga, representatives of taiga flora appear in the grass cover" [46].

If we consider present-day forestation processes of steppe territories within a zonal forest-steppe (the Selenga R. basin) at a contact site with Central Asia steppe zone, this will be probably mainly spatial re-distribution of territories occupied by forest and steppe cenoses with time with possible change of the forest-steppe boundary in latitudinal direction due to climatic fluctuations for a concrete time period on the background of forcing of processes of anthropogenic impact onto the environment. Under the conditions of contact between zonal steppe and zonal forest-steppe, phytocenoses which are just to be called ecotones form-these are transitional cenoses 
between environmental zones. An interzonal ecotone, in this case-one between zonal steppes and zonal foreststeppes, reflects a spatial-temporal variability of vegetation structure at definite environmental and climatic conditions. At humidity increase, a shift of forest-steppe boundary towards the steppes zone (in latitudinal direction) is observed as forestation of steppe territories both within forest-steppe zones and at a contact site of steppe and forest-steppe zones, respectively. Here one can suppose that at income of a dry period, one forecast extention of steppes zone toward the forest-steppe zone with extention of steppe territories within forest-steppes. It occurred just in recent past—at different Holocene stages in Siberia [38]. Due to this, the interzonal ecotone suggests spatial-temporal variability of the vegetation development in environmental zones. On the background of climate dynamics during last decades taking into account the decrease of pasturage charge, there is on this key site in a whole a leveling of the boundary between forest and steppe cenoses. An abundant undergrowth out of the timber stand canopy and its presence within steppe cenoses suggest tendencies to extention of a forest component in the vegetation structure. This is a natural process of vegetation cover formation for a zonal forest-steppe. Main factor of constraint of forestation processes on steppe sites within zonal forest-steppe will be increase of pasturage charge on the background of abrupt climate changes; this can often result in fires danger in the region.

There is a following conclusion for this key site. Due to climate change (increase of mean annual temperatures and humidity increase at last stages of vegetation), on the background of the past period of aridization (Late Holocene), processes of forests reconstitution instead of steppe territories occur everywhere. On the background of pasturage charge decrease during last decades, the grasses are reconstituted rather slowly (division into horizons, increase of projective cover, increase of species diversity). Due to these processes, change of forest-steppes boundary in the latitudinal direction B (forestation of steppe territories everywhere) is possible; this reflects a permanent state of "steppe islands" for a concrete time period. This is confirmed as well by the availability of sod-forest (forest zone soils) soils with processes of soils formation according to the "forest" type. It is to consider here increase of anthropogenic impact, mainly pasturage regime accompanied often by periodic fires (grassland fires) as a constraint factor for vegetation formation.

\subsection{Key Site-Middle Part of the Barguzin Depression (North-Eastern Coast of Lake Baikal)}

Characteristic forests for the Barguzin Depression are mountain taiga ones of Baikal-Dzhugdzhur formation of Argada fratria together with piedmont-depressional light coniferous ones of South-Siberian formations. Larixpine suffruticous-green mosses forests with underbrush of rhododendron and Duschekia fruticosa form along the depression boards and slopes aprons of mountain surrounding (Barguzin and Argada Ridges). The bottom of Barguzin Depression itself is mainly ploughed up, and at yields margin, forbs-cereals cenoses of South-Siberian formations occur [40]. Steppe cenoses represent abzonal (extrazonal) inclusions within taiga zones of NorthEastern Trans-Baikal. According to botanic-geographic subdivision, one of key sites, Barguzin Depression, does not belong to any area subarea or province of Eurasian forest-steppes [43] and Central Asian steppes [44]. Cenoses with some forest plant species form on the aprons of the depression surroundings, at the place of forbscereal steppe cenoses of anthropogenic series (former pastures). There are among them numerous pine sprouts and undergrowth out of a closed timber stand. It is to notice here that much attention is paid to the processes of dynamics of species composition of Barguzin Depression steppe cenoses from the viewpoint of plants ecological groups proportion reflecting some dynamical tendencies in the vegetation formation [47]-[49]. It is stated in particular that recently, due to increase of habitats humidity on the slopes of forest belt, the positions of xerophytes weaken. At the same time, processes of strengthening of steppe (xerophytes) plants species due to elimination of steppe species are observed in the steppe cenoses of the depression bottom and of slopes aprons; this is prescribed to climate aridization in the depression on the background of its general warming [49]. It is concluded that the process has two directions - both aridization (warming) and mesophytization or the result of combination of both climatic trends characterizing climatogenic dynamics of vegetation in the studied area [47] [49]. There are several publications on this topic as well for other Siberian regions. It is to notice that climatogenic dynamics as a permanent process is a mode (base) of this phenomenon, which will be always available in vegetation development.

Probably, in this case we have to speak about climatogenic succession as about a process where there is a given reference point of phytocenoses state under concrete physical-geographical conditions for a definite territory for a concrete time period leading to formation of a qualitatively different morphology of a cenoses differing 
from one available at the reference point. From our viewpoint, the climatogenic successions reflect paragenese in vegetation organization, which is suggested by the results of the studies performed, including the analysis of the composition of geoelements and ecotypes of plants species in the cenoses from the studied area. Main feature of vegetation structure in Barguin Depression in the whole is formation of pine forests together with steppe cenoses of depression bottoms and of slopes aprons of different expositions. Steppe cenoses consist of large cereals steppes with domination of Stipa krylovii Roshev., Agropyron cristatum (L.) Beauv. The sites occupied by these cenoses were ploughed up in the middle period of the last century. It is noticed that here there are no fescue (Festuca lenensis Drobov) steppes characteristic for the whole Trans-Baikal, but there are instead of them well developed steppes with domination of Artemisia obtusiloba ssp. subviscosa (Turcz. ex Besser) Krasnov and with large distribution of Artemisia frigida Willd. The cereal component of the cenoses includes such species as Agropyron cristatum (L.) Beauv., Poa botryoides (Trin. ex Griseb.) Kom., Cleistogenes squarrosa (Trin.) Keng. Among forbs, there are in abundance Potentilla acaulis L., Oxytropis oxyphylla (Pallas) DC., Papaver nudicaule L., Potentilla bifurca L., Chamaerhodos erecta (L.) Bunge., Delphinium grandiflorum L. and Thymus serpyllum L. There are well developed cenoses with domination of Poa botryoides (Trin. ex Griseb.) Kom., Bupleurum bicaule Helm. and Artemisia obtusiloba ssp. subviscosa (Turcz. ex Besser) Krasnov. There are significant groups with domination of Stipa krylovii Roshev. A significant cenoses differentiation by their species and quantitative composition related to concrete depression territories is observed in the spatial structure of Barguzin Depression.

The base of modern vegetation of this key site is larch (Larix sibirica Ledeb.)-pine (Pinus sylvestris L.) forbs-stepped thinned forests with pine undergrowth and sprouts in combination with steppe cenoses in which there are clumps of pine undergrowth and sprouts, especially on the territories not impacted by ploughing up. The main horizon is dominated by pine, larch is co-dominant. The undergrowth is abundant and is spread out of the canopy. The brush horizon consists of Rhododendron dahuricum L., Spiraea media Franz Schmidt., Rosa acicularis Lindley. The surface cover is characterized by Dianthus versicolor Fischer ex Link, Veronica incana L., Allium tenuissimum L., Stipa krylovii Roshev., Artemisia obtusiloba ssp. subviscosa (Turcz. ex Besser) Krasnov, Galium verum L., Patrinia rupestris (Pallas) Dufr., Elytrigia repens (L.) Nevski. There are synusias of Abietinella abietina (Turn.) Fleisch., Rhytidium rugosum (Hedw.) Kindb. Typical for polydominant dark coniferous-light coniferous Pre-Baikalian taiga. Basic modern vegetation of this key sites are forbs-stepped thinned pine forests with pine undergrowth in combination with steppe cenoses with clumps of pine undergrowth and sprouts, especially on the territories not impacted by ploughing up. Modern tendencies are characterized by forestation processes everywhere in steppe space. Under the conditions of contact of forests and extrazonal steppes of depression types, cenoses with plants species from different environmental confinedeness form resulting from environmental specifics.

The dominant families (Asteraceae, Poaceae, Cyperaceae, Fabaceae, Apiaceae, Brassicaceae, Ranunculaceae, Caryophyllaceae) form major part of plants species mentioned in geobotanical descriptions of different years and vegetation periods for the key site. This set of dominant families is very characteristic for boreal floras and is similar to the family spectrum for East Siberian flora [26]-[28] [50] [51]. The Holarctic Region is characterized by dominance of the families Asteraceae and Poaceae. Boreal floras are characterized in the whole by high positions of the family Cyperacea and significant one for the family Ranunculaceae. Continental features of floras are manifested by the significant role of the families Brassicacea, Rosaceae, Fabaceae [28]-[30]. The family spectrum represents the most common peculiarities of the flora due to its zonal position (taiga zone). The genus spectrum manifests as well the boreal character of the flora and reflects mainly provincial peculiarities of the cenoses of contact between taiga and extrazonal steppes of depressional type in the Baikal Region. Among all plants species in the cenoses of the key site, the forest-steppe belt-zonal group [21] includes not more than 15\% of total species composition. Consequently, the belt structure is not expressed in the studied area, and it is doubtful that we have right to characterize the cenoses of contact between taiga and extrazonal steppes of the key sites as a mountain-forest-steppe belt.

Among main (the most occurring plants species in geobotanical descriptions) floristic composition (see Table 2), the fraction of North-Asian, Eurasian, South-Siberian and Holarctic geoelements include ca. $90 \%$ of all species composition, while Central-Asian, East-Asian and All-Asian geoelements are represented by several plants species. According belt-zonal groups, the base consists of light coniferous forest and forest-steppe groups with inclusions of species of dark coniferous forest and pre-boreal groups of plants species. In major part of cenoses habitats (on the base of geobotanical descriptions) there are moss species appropriate to polydominant dark con- 
iferous—light coniferous forests. These are such species as Rhytidium rugosum (Hedw.) Kindb., Polytrichum juniperinum Hedw., Pleurozium schreberi (Brid.) Mitt., Ptilium crista-castrensis (Hedw.) De Not., Abietinella abietina (Turn.) Fleisch., Dicranum polysetum Sw. The species composition of cenoses forming under the conditions of extrazonality of steppes of depressional type (Barguzin Depression) reflects paragenese in the general structure of vegetation cover in this part of the Baikal region. This is suggested as well by performed soil-geobotanic profiling which has shown the absence of direct connection of phytocenoses with soils types. Soddy brown soils and maroon ones related to the depression bottom are developed in the region. Nevertheless, both larch-pine forests and cereal-forbs steppe cenoses with a pine undergrowth everywhere, including steppes form on these soils. The ecotypes composition is represented by domination of plants species of mesophytic ecology with a very insignificant presence of xerophytes themselves and of cryoxerophites among key site cenoses. As the key site (Barguzin Depression) is in the mountain taiga zone (North-Eastern coast of Lake Baikal), and steppe cenoses (depressional type) on the bottom of the depression itself have extrazonal nature, the ratio of ecotypological and arealogical flora composition in the studied area is rather obvious (see Table 2).

Essentially, the cenoses in the studied area reflect the peculiarities of relations and spatial variation between forests and extrazonal steppe cenoses. These cenoses formed by plants species with different ecological amplitudes respond very rapidly and reflect visually quite distinctly changes in ecotopes conditions at topological and regional levels of environment organization. Such cenoses can serve as representative models reflecting structural-dynamical peculiarities of the vegetation in the region on the background of climate dynamics during last decades. The comparative analysis of areas occupied by forest and steppe cenoses showed tendencies to a gradual forestation of steppe space, especially in lower parts of graded ridge slopes in the depression surroundings. Steppe cenoses (listed on the base of summarized geobotanical descriptions and vegetation periods) are forbs-cereal plants groups with inclusions in them of pine of different age (5 - 25 y.o.) heterogenous by distribution territory. Forests (listed on the base of summarized geobotanical descriptions and vegetation periods) are larch-pine, pine brush forbs forests together with open stepped ones with pine undergrowth forests at the boundary with extrazonal (depression type) steppes of bottom and slopes aprons on the depression boards. Ploughed fields are soils ploughed up in 1950ies, representing now perennial yields, territories with tendencies of formation here of plants groups of steppe types at first stage. Pine undergrowth is rare.

Modern tendencies of vegetation development in the studied area reflect a transitional character of steppes with tendencies with tailing of boundary between forest and steppe cenoses. The appearing of pine undergrowth in extrazonal steppes can suggest that in the region, together with forests reconstitution dynamics, the structure of steppe cenoses changes as a response to changing climatic situation. This is just confirmed by natural forestation of extrazonal steppes in the whole Barguzin Depression. Further cenoses development in the studied area from the viewpoint of structural changes on the background of climatic factors fluctuations will go towards forests formation with presence of small territories occupied with xerophyte-petrophyte grass groups on stony substrates and ridges. These processes may be constrained by the character of anthropogenic impact or by abrupt climate changes in the region making climate dryer.

Forestation of extrazonal steppe of Barguzin Depression (North-Eastern coast of Lake Baikal) as paragenesis (object) suggests changes in natural climatic conditions in the region, when steppe territories in some way "compress" by their territory for a concrete time period. It means that for last decades, this process has a regional scale. And in this case, as it was mentioned before, it is to notice that "A forest of this or that kind, composition or structure will obviously cover earlier or later steppe spaces at least by park plants but with keeping of small steppe "islands" due to increase of climate dryness in the beginning of the century" [22] [23].

\section{Conclusions}

The cenoses at such key site such as middle part of the Selenga River basin, South-Western Pre-Baikal—-territory on the junction site of mountain forest-steppes and steppe zone of Central Asian (Daurian-Mongolian) subregion of a steppe region-represent an interzonal ecotone. This is suggested by the results of analysis of geoelemental and ecotypological (ecotypes) compositions, of belt-zonal groups of plants species and the composition of dominant families. By species composition, key site cenoses are more related to the forest-steppe zone but with presence of species representing North-Asian steppes. For the territory of the studied area, zonal forest-steppe soils are characteristic. Climate change during last decades in this region is manifested by humidity and temperature increase. Decrease of anthropogenic pression results as well both in forestation of steppe space within the 
Table 2. Common table of plants species characteristic for model territories of Barguzin Depression key site.

\begin{tabular}{|c|c|c|c|c|c|}
\hline \multicolumn{6}{|c|}{ Geoelemental and ecotypological composition of the basic plant species of the key area } \\
\hline Plant species & Geoelement & Ecotype & Plant species & Geoelement & Ecotype \\
\hline Pinus sylvestris & EA & $\mathrm{XM}$ & Artemisia frigida & CP (HA) & $\mathrm{CrX}$ \\
\hline Populus tremula & EA & $\mathrm{XM}$ & Thymus serpyllum & SC & $\mathrm{XT}$ \\
\hline Rhododendron dahuricum & MD & MT & Potentilla acaulis & CA & XT \\
\hline Spiraea media & EA & MT & Artemisia gmelinii & NA & CrX \\
\hline Artemisia subviscosa & EN & MX & Bupleurum scorzonerifolium & E-A & $\mathrm{XM}$ \\
\hline Dianthus versicolor & EA & MX & Leontopodium ochroleucum & C-A & $\mathrm{CrX}$ \\
\hline Veronica incana & NA & MX & Phleum phleoides & ES & XM \\
\hline Orostachys spinosa & CA & CrX & Spiraea flexuosa & MD & MT \\
\hline Iris ruthenica & NA & MT & Agropyron cristatum & CA & $\mathrm{XM}$ \\
\hline Poa botryoides & NA & MX & Artemisia commutata & NA & MX \\
\hline Allium tenuissimum & SC & $\mathrm{XM}$ & Scabiosa comosa & SC & $\mathrm{XM}$ \\
\hline Rosa acicularis & CP (HA) & MT & Linum sibiricum & EA & MX \\
\hline Bergenia crassifolia & SC & MT & Scorzonera radiata & NA & XM \\
\hline Vaccinium vitis-idaea & CP (HA) & XM & Draba nemorosa & CP (HA) & MT \\
\hline Trollius asiaticus & SC & MT & Poa sibirica & NA & XM \\
\hline Chelidonium majus & EA & MT & Bupleurum bicaule & MD & CrX \\
\hline Vicia baicalensis & E-A & MT & Galium boreale & CP (HA) & MT \\
\hline Sanguisorba officinalis & $\mathrm{CP}(\mathrm{HA})$ & MT & Myosotis suaveolens & EA & MX \\
\hline Leucanthemum vulgare & EA & $\mathrm{XM}$ & Leontopodoium leontopoides & MD & CrX \\
\hline Goniolimon speciosum & EA & HalXM & Koeleria cristata & CP (HA) & $\mathrm{XT}$ \\
\hline Stipa krylovii & C-A & $\mathrm{XM}$ & Schizonepeda multifida & NA & MX \\
\hline Cotoneaster melanocarpus & EA & $\mathrm{XM}$ & Astragalus versicolor & SC & $\mathrm{XM}$ \\
\hline Carex macroura & NA & MT & Androsace incana & SC & $\mathrm{CrX}$ \\
\hline Carex pediformis & EA & MX & Galium verum & CP (HA) & MT \\
\hline Polygonatum sibiricum & CA & MT & Thalictrum foetidum & EA & XM \\
\hline \multirow[t]{5}{*}{ Patrinia rupestris } & SC & CrX & Pulsatilla multifida & СР (HA) & $\mathrm{XM}$ \\
\hline & & & Phlomis tuberosa & EA & $\mathrm{XM}$ \\
\hline & & & Aster alpinus & CA & CrX \\
\hline & & & Artemisia laciniata & NA & MX \\
\hline & & & Carex korshinskyi & E-A & MX \\
\hline
\end{tabular}

Table legend: EA—Eurasian geoelement; SS—South-Siberian and Mongolian ones; NA—North-Asian one; AA—All-Asian one; ES—Euro-Siberian one; C-A—Central Asian one; KC (HA) — circumpolar (boreal Holarctic one); E-A—East-Asian one; MD-Manchuria-Daurian one; EN-hemiendemic geoelement; MX - mesoxerophytes; XM—xeromesophytes; MT—mesophytes themselves; XT—xerophytes themselves; HalMX-hallomesoxerophytes; CrX-Cryoxerophytes. 
steppe zone and in extention of trees species towards steppes. Thus, there is a tendency of forest-steppe zone shifting in latitudinal direction with formation to some degree of light coniferous forests of zonal type. At the boundaries of environmental zones where ecotones form as transitional systems at changing heat and humidity ratio, their considerable territorial "widening" (or "narrowing" at other scenarios of climate changes) occurs. This is just seen at the sites of relative spatial "widening" of the ecotone between forest-steppe (mountain forest-steppes) and steppe environmental zones of South-Eastern Trans-Baikal.

Species composition and structure of phytocenoses at the key site (within Barguzin Depression) reflect the specifics of vegetation formation under the conditions of extrazonality of steppe cenoses contacting with polydominant light coniferous forests, often with inclusions of dark coniferous species in the undergrowth and in the second horizon. There are among forests vegetation groups where species composition is based on xerophytes of steppe environmental zone. Soils of the key site (Barguzin Depression) are characterized as extrazonal (cryoarid) ones; they do not reflect direct connection with species composition and phytocenoses types on this territory. Both forest and steppe cenoses develop on the same soils; it was revealed at combined soil-geobotanic profiling of key sites. Such cenoses reflect paragenese (object) in organization of vegetation cover on a concrete territory. Paragenese in vegetation structure means cenoses reflecting structure and dynamics of environmental conditions of regional-topological level of environment organization within environmental zones during a definite time period on a concrete territory. Decrease of areas occupied by extrazonal steppe cenoses in forest zone during last decades allows to speak about rather considerable climate changes and about anthropogenic impact in the region. Forest cenoses with rather sustainable renewal, often with synusia of mosses characteristic for polydominant dark coniferous-light coniferous taiga form intensively among steppe sites. Under the conditions of steppes extrazonality and of non-expressed mountain steppe and mountain-forest-steppe belts, particular cenoses which are to be called taiga-steppe ones form in the studied area. Taking into account the peculiarities of modern state and development vector of taiga-steppe cenoses of the studied area (Barguzin Depression), we have to wait for formation of light coniferous taiga with dark coniferous species in perspective, as there are here tendencies to strengthening of their positions such as considerable amount of dark coniferous species in the second horizon and in pine forests undergrowth on the studied territory. Under paragenese conditions (within environmental zones) as in definite environments differing by heat and humidity ratio, by radiation balance at climate change, mainly towards precipitation increase, an environmental site is "narrowing" (in our case this is forestation of extrazonal steppes within zonal taiga) during a concrete time period at a definite site. This was just found out at the example of vegetation structure of a key site in the Baikal Region—Baikal Depression. This environmental site can "widen" as well in space due to increase of xerophytation processes (at increase of climate dryness) within taiga zone vegetation cover. However, these processes will depend on vector and character of anthropogenic impact on the background of climate dynamics, mainly on moistening.

The ecological and biocenological role of ecotones and cenoses reflecting paragenese (object) in the vegetation structure of the Baikal region is in revealing of phytocenotic and typological diversity of cenoses, in indication of structural-dynamic organization and in forecast of vegetation development under concrete physical geographical conditions at vaste territories including zonal and intrazonal differences of environments determining different degree of natural and anthropogenic resistance of the whole vegetation cover.

\section{References}

[1] Walter, H. and Box, E. (1976) Global Classification of Natural Terrestrial Ecosystems. Vegetatio, 32, 75-81. http://dx.doi.org/10.1007/bf02111901

[2] Voronkov, O.A., Tarasov, A.O. and Sukachev, V.S. (1993) Some Peculiarities of Forest Edges as Ecotones. Botanics of the Volga River Basin, Saratov, 8-15.

[3] Kucherova, S.V. and Mirkin, B.M. (2001) On the Methods for Analyses of Forest Edges Ecotones. Ecology, 5, 339342.

[4] Neronov, V.V. (2008) Zonal Ecotones of Northern Eurasia: Studies History and Structural-Functional Organization. Success of Modern Biology, 1, 35-51.

[5] Grishankov, G.Ye. (1977) Paragenetic Systems of Environmental Zones (Crimea). Systematic Studies of Nature, Nauka, Moscow, 128-139.

[6] Krut', I.V. (1978) Introduction to General Earth Theory. Mysl’, Moscow, 367.

[7] Kulikov, A.I., Bazhenov, V.S. and Ivanov, N.V. (2006) Soils Paragenesis and Paradynamics. Buryat Scientific Center 
Publishing House, Ulan-Ude, 280.

[8] Mil’kov, F.N. (1986) Physical Geography. Landscapes Science and Geographical Zonality. Voronezh State University Publishing House, Voronezh, 328.

[9] Shvebs, G.I. (1981) Theoretical Basis of Erosion Science. Vishcha Shkova, Kiev, 222.

[10] Vasilyev, S.V. (2007) Paragenesis. In: Forest and Swamp Landscapes of Western Siberia, Tomsk Publishing House of Scientific and Technical Literature of RAS SB, 24-29.

[11] Yevdokomov, L.A. (1979) Materials on Paragenesis of Flora and Vegetation at Phytocenotic Level. Vegetation Cover Morphology and Dynamics. Scientific Notes of Kuybyshev Pedagogical Institute, Kuybyshev, 229, 11-16.

[12] Sochava, V.B. (1979) Vegetation Cover on Thematic Maps. Nauka, Novosibirsk, 189.

[13] Flora of Siberia (1987-1997), Nauka, Novosibirsk, 1-14.

[14] Flora of Central Siberia (1979) Nauka, Novosibirsk, 1-2, 1047.

[15] Summary of Siberian Flora (Vascular Plants) (2005) Nauka, Novosibirsk, 362 p.

[16] Summary of Flora of Asian Russia (2012) Vascular Plants. Central Siberia Botanic Garden Publishing House, Novosibirsk, 638.

[17] Bardunov, L.V. (1969) Key of Cormophyte Mosses of Central Siberia. Nauka, Leningrad, 330.

[18] Bardunov, L.V. (1992) Summary of Siberian Brioflora. Nauka, Novosibirak, 97.

[19] Alyokhin, V.V. (1950) Plants Geography. Uchpedgiz, Moscow, 420.

[20] Wulf, Y.V. (1944) Historical Geography of Plants (History of Globe Floras). USSR AS Publishing House, Moscow-Leningrad, 545.

[21] Malyshev, L.I. and Peshkova, G.A. (1984) Peculiarities and Genesis of Siberian Flora. Pre-Baikal and Trans-Baikal, Nauka, Novosibirsk, 264.

[22] Popov, M.G. (1957) Flora of Middle Siberia. Vol. 1, USSR AS Publishing House, Moscow-Leningrad, 556.

[23] Popov, M.G. (1959) Flora of Middle Siberia. Vol. 2, USSR AS Publishing House, Moscow-Leningrad 557-918.

[24] Serebryakov, I.G. (1962) Ecological Morphology of Plants. Vyschaya Shkola, Moscow, 378.

[25] Serebryakov, I.G. (1964) Vital Forms of Higher Plants and Their Studies. In: Field Geobotanics, Vol. 3, Nauka, Moscow-Leningrad, 146-205.

[26] Tolmachev, A.I. (1970) On Some Quantitative Ratios in Global Floras. Bulletin of Leningrad University, 15, 62-74.

[27] Tolmachev, A.I. (1974) Introduction in Plants Geography. Nauka, Leningrad, 244.

[28] Schmidt, V.M. (1983) Statistic Methods in Comparative Floristics. Nauka, Leningrad, 176.

[29] Yurtsev, B.A. (1966) Hypoarctic Botanical-Geographical Belt and Origin of Its Flora. Nauka, Moscow-Leningrad, 94.

[30] Yurtsev, B.A. (1976) Vital Forms: One of Key Subjects of Botany. In: Problems of Plants Ecological Morphology, Nauka, Moscow, 9-44.

[31] Korotkiy, M.F. (1912) Barguzin Steppes. Preliminary Report on Soils Studies in Asian Russia in 1911, Saint-Petersburg.

[32] Korotkiy, M.F. (1913) Yeravnoye Steppes. Preliminary Report on Organization of Activities for Soils Studies in Asian Russia in 1912, Saint-Petersburg.

[33] Korotkiy, M.F. (1916) Steppe Phenomena in Barguzin Taiga (Expedition to the Muya, R.). Preliminary Report on Botanical Studies in Siberia and Turkestan in 1914, Saint-Petersburg, 63-99.

[34] Korotkiy, M.F. (1916) Expedition to the Muya, R. Preliminary Report on Soil Studies in Asian Russia in 1914, Saint-Petersburg, 181-217.

[35] Ral'din, B.B., Unugunov, L.L., Khertuev, V.N. and Shagzhiev, K.S.H. (2003) Geoecological Aspects of Land Use in Buryat Republic. Publishing House of Buryat Scientific Center of RAS, Ulan-Ude, 10-16.

[36] Belov, A.V. and Sokolova, L.P. (2013) New Review-Information Map of the Baikal Region Vegetation. Geografia $i$ Prirodnye Resursy, 3, 118-131.

[37] Molozhnikov, V.N. (1986) Phytocenoses of Pre-Baikal. Nauka, Novosibirsk, 272.

[38] Reshetova, S.A., Bezrukova, Y.V., Panizdo, V., Henderson, E., Ptitsyn, A.B., Daryin, A.V. and Kalugin, I.A. (2013) Vegetation of Central Trans-Baikal during Late Glaciation and Holocene. Geografia i Prirodnye Resursy, 2, 110-117.

[39] Bezdelova, A.P. (2006) Peculiarities of Zonal Position of Trans-Baikal as a Basis of Development of Vegetation Cover Steppification in the Region. In: Steppes of North Eurasia, Gazprom Publisher of Orenburg Gazprom Service Ltd., Orenburg, 99-102. 
[40] Vegetation in the South of East Siberia (Map. Scale 1: 500 000) (1972) Geodesy and Mapping Head Office, Moscow.

[41] Zones and Types of Vegetation Belts in Russia and in Adjacent Countries (Scale 1: 8000000) (1999) Moscow State University Publishing House, Moscow.

[42] Lavrenko, Y.M. (1970) Provincial Subdivision of Central Asian Subregion of Eurasian Steppe Region. Botanicheskiy Jurnal, 55, 1734-1747.

[43] Lavrenko, Y.M., Ed. (1991) Steppes of Eurasia. Nauka, Leningrad, 145.

[44] Khmelev, V.A., Ed. (2002) Steppes of Central Asia. Nauka, Novosibirsk, 296.

[45] Reymers, N.F. (1994) Ecology (Theory, Laws, Rules, Principles and Hypotheses). Rossiya Molodaya, Moscow, 367.

[46] Vipper, P.B. (1963) Interaction of Forest and Steppe in the South-Western Part of Buryat Republic. Proceedings of Studies of Siberia and Far East Forest, Forest Institute of USSR AS SB Publishing House, Krasnoyarsk, 315-317.

[47] Anenkhonov, O.A. and Krivonogov, L.V. (2006) Tendency of Change of Floristic Composition of Forest Vegetation in North Pre-Baikal at Climate Warming. Ecology, 4, 280-286.

[48] Krivonogov, L.V. and Anenkhonov, O.A. (2010) Tendency of Change of Floristic Composition of Steppe Vegetation in North Pre-Baikal. Vegetation Cover of Asian Russia, 6, 17-21.

[49] Anenkhonov, O.A. (2011) “Traces” of Climate Change in Trans-Baikalian Ecosystems. Soils and Biota Diversity in North and Central Asia: Abstract for an International Conference, Ulan-Ude, 98-100.

[50] Polozhiy, A.V. (1965) Ecological-Geographical Analysis of Legumes Family in Central Siberia Flora. Scientific Letters of Tomsk University, 51, 39-48.

[51] Malyshev, L.I. (1972) Floristic Spectra of the Soviet Union. In: History of Eurasian Flora and Vegetation, Nauka, Leningrad, 17-40.

\section{Submit or recommend next manuscript to OALib Journal and we will provide best service for you:}

- Publication frequency: Monthly

- 9 subject areas of science, technology and medicine

- Fair and rigorous peer-review system

- Fast publication process

- Article promotion in various social networking sites (LinkedIn, Facebook, Twitter, etc.)

- Maximum dissemination of your research work

Submit Your Paper Online: Click Here to Submit

Contact Us: service@oalib.com 